\title{
ANALISIS EFISIENSI EKONOMI PENGGUNAAN FAKTOR-FAKTOR PRODUKSI PADA USAHATANI PADI DI KELOMPOK TANI SIDOMAKMUR I KECAMATAN PATI KABUPATEN PATI
}

\author{
Ayu Dwi Maharani ${ }^{1)}$, Edy Prasetyo²), Bambang Mulyatno Setiawan ${ }^{3)}$ \\ ${ }^{1)}$ Fakultas Peternakan dan Pertanian, Jurusan Agribisnis, Universitas Diponegoro, Jl. Prof. Soedarto S.H \\ Tembalang Semarang, Telp. (024) 7460024, email: ayudwimaharani@gmail.com \\ ${ }^{2)}$ Fakultas Peternakan dan Pertanian, Jurusan Agribisnis, Universitas Diponegoro, Jl. Prof. Soedarto S.H \\ Tembalang Semarang, Telp.—, email: edyprsty@yahoo.com \\ ${ }^{3)}$ Fakultas Peternakan dan Pertanian, Jurusan Agribisnis, Universitas Diponegoro, JI. Prof. Soedarto S.H \\ Tembalang Semarang, Telp._, email: b_mulyatno@yahoo.co.id
}

\begin{abstract}
Abstrak
Penelitian ini bertujuan menganalisis pengaruh jumlah penggunaan faktor-faktor produksi terhadap produksi usahatani padi dan menganalisis tingkat efisiensi ekonomi penggunaan faktor-faktor produksi usahatani padi di Kelompok Tani Sidomakmur I Kecamatan Pati Kabupaten Pati. Penelitian dilaksanakan pada Desember 2017 sampai Januari 2018 di Kelompok tani Sidomakmur I Kecamatan Pati Kabupaten Pati. Metode penelitian yang digunakan adalah survei.Pengambilan sampel menggunakan metode simple random sampling dengan jumlah responden 51 petani dari populasi sebanyak 105 petani.Data dianalisis menggunakan regresi linier berganda yang ditransformasikan ke dalam bentuk fungsi produksi model CobbDouglas dan perhitungan efisiensi ekonomi. Hasil penelitian menunjukkan bahwa faktor produksi luas lahan, benih, pupuk NPK dan pestisida berpengaruh terhadap produksi padi sedangkan pupuk urea dan tenaga kerja tidak berpengaruh terhadap produksi padi. Penggunaan faktor produksi luas lahan, benih, pupuk urea, pupuk NPK dan pestisida secara ekonomi belum efisien sedangkan penggunaan faktor produksi tenaga kerja secara ekonomi tidak efisien.
\end{abstract}

Kata Kunci : efisiensi ekonomi, faktor-faktor produksi, usahatani padi.

\begin{abstract}
This study aims to analyze the influence of production factors to production of rice farming and analyze the level of economic efficiency of the production factors usage on rice farming in Sidomakmur I farmer group Pati District Pati Region. The study was conducted from December 2017 until January 2018 in Sidomakmur I farmer group Pati Distric Pati Regency. The method used in the study was survey. Sample was taken by simple random sampling method with the number of respondent as many as 51 farmers from the population of 105 farmers. Data were analyzed by multiple linier regression which is transformed into a Cobb-Douglas model production function and economic efficiency calculation. The result showed that the production factors of land area, seed, NPK fertilizer and pesticides have an effect on rice production while urea fertilizer and labor have no effect on rice production. The use of production factors of land area, seed, urea fertilizer, NPK fertilizer and pesticides are economically inefficient while the use of labor production factors is not efficient.
\end{abstract}

Keywords : economic efficiency, factors of production, rice farming.

\section{PENDAHULUAN}

Pertanian merupakan sektor ekonomi berperan penting dalam pembangunan yang mempunyai peranan penting di Indonesia. pertanian dan penyediaan pangan dalam Sektor pertanian sangat strategis sebagai basis rangka mewujudkan ketahanan pangan, ekonomi rakyat di pedesaan. Sektor pertanian ekonomi, sosial, politik dan keamanan nasional, 
Agrisaintifika

Jurnal Ilmu-Ilmu Pertanian

Vol. 3, No. 1, 2019

Maharani, et.al. 2017

terutama subsektor pertanian tanaman pangan (Arifin, 2005). Subsektor tanaman pangan berperan untuk memenuhi kebutuhan bahan pangan pokok masyarakat. Indonesia memiliki beraneka ragam jenis tanaman pangan yang dapat dimanfaatkan sebagai bahan makanan penghasil karbohidrat, salah satunya yaitu nasi yang berasal dari tanaman padi.

Tanaman padi sawah (Oryza sativa L.) merupakan tanaman pangan dengan kandungan nutrisi yang diperlukan tubuh yaitu karbohidrat, lemak dan protein. Kandungan karbohidrat pada tanaman padi sawah sebesar $78,9 \%$, protein $6,8 \%$, lemak $0,7 \%$ dan lain-lain $0,6 \%$. Tanaman padi merupakan tanaman yang istimewa karena mempunyai kemampuan beradaptasi hampir pada semua lingkungan, dari dataran rendah sampai dataran tinggi.

Tanaman padi sawah (Oryza sativa L.) adalah tanaman pangan yang sangat penting di Indonesia karena sebagai makanan pokok dan ketersediaannya harus tercukupi sepanjang tahun. Kebutuhan beras secara nasional terus meningkat seiring dengan meningkatnya jumlah penduduk. Beras ini diupayakan ketersediaanya tercukupi sepanjang tahun, karena penduduk Indonesia menjadikan beras sebagai bahan makanan pokok. 95\% penduduk Indonesia mengkonsumsi bahan makanan ini (Swastika et al., 2007).

Kabupaten Pati merupakan salah satu lumbung padi yang menyokong produksi pangan di Provinsi Jawa Tengah karena termasuk dalam 4 besar kabupaten dengan produksi padi sawah tertinggi (BPS Jawa Tengah, 2016). Produksi padi sawah di
Kabupaten Pati pada tahun 2015 yaitu 631.899 ton dengan luas panen 106.049 ha dan produktivitas sebesar 59,59 kw/ha. Kontribusi produksi padi Kabupaten Pati terhadap Jawa Tengah pada tahun 2015 yaitu 631.899 ton dari jumlah keseluruhan 11.006 .570 ton atau $5,74 \%$ dari total keseluruhan. Produksi padi sawah di Kabupaten Pati secara keseluruhan mengalami peningkatan, namun sempat terjadi penurunan pada tahun 2014 yaitu produksi padi sawah sebanyak 484.466 ton dengan luas panen 89.208 ha dan produktivitas sebesar $54,31 \%$ (BPS Kabupaten Pati, 2016).

Kecamatan Pati merupakan salah satu kecamatan yang memiliki produksi padi yang tinggi. Produksi padi sawah pada tahun 2014 sebesar 205.714 ton dengan luas panen 3.500 ha dan produktivitas $58,78 \mathrm{kw} / \mathrm{ha}$ (BPS Pati, 2016). Luas panen tersebut mengalami penurunan yang cukup drastis dari tahun sebelumnya. Penurunan produksi tersebut sangat merugikan bagi petani, berdasarkan hal tersebut produktivitas padi di Kecamatan Pati perlu ditingkatkan.

Usahatani padi sawah dijalankan dengan mengkombinasikan beberapa faktor produksi sedemikian rupa sehingga dapat menghasilkan output yang dapat menghasilkan keuntungan. Kurang tepatnya penggunaan kombinasi faktorfaktor produksi akan mengakibatkan rendahnya hasil produksi. Peningkatan produksi dapat dilakukan dengan memanfaatkan faktor-faktor produksi secara efisien, artinya hasil produksi yang dihasilkan lebih besar dari faktor-faktor produksi yang digunakan, dengan kata lain penerimaan lebih besar dari biaya yang 
Agrisaintifika

Jurnal Ilmu-Ilmu Pertanian

Vol. 3, No. 1, 2019

Maharani, et.al. 2017

dikeluarkan sehingga pendapatan meningkat. Pilihan terhadap kombinasi penggunaan tenaga kerja, bibit, pupuk, pengolahan lahan, perawatan tanaman serta penggunaan modal dan teknologi yang tepat akan meningkatkan produktivitas lahan pertanian atau kombinasi input yang tepat akan menciptakan sejumlah produksi yang efisien (Sukirno, 2000).

Penelitian ini bertujuan untuk menganalisis pengaruh penggunaan faktorfaktor produksi terhadap kuantitas produksi dan menganalisis tingkat efisiensi ekonomi penggunaan faktor-faktor produksi pada usahatani padi di Kelompok tani Sidomakmur I Kecamatan Pati.

\section{METODE PENELITIAN}

Penelitian dilaksanakan pada bulan Desember 2017 sampai Januari 2018 di Kelompok Tani Sidomakmur I Kecamatan Pati Kabupaten Pati. Pemilihan lokasi ini didasarkan atas pertimbangan yaitu kelompok tani Sidomakmur I merupakan kelompok tani yang aktif dalam pemberdayaan petani melalui perkumpulan petani, menerapkan sistem irigasi secara teknis sejak tahun 1991 dan memiliki organisasi pengairan yang bernama Darmatirta Sidomakmur.

Metode yang digunakan dalam penelitian ini adalah survei. Metode survei adalah penelitian yang mengambil sampel dari satu populasi dan menggunakan kuesioner sebagai alat pengumpulan data pokok (Singarimbun dan Effendi, 2006).

Pengambilan sampel responden menggunakan metode simple random sampling. Metode simple random sampling adalah dikatakan simple (sederhana) karena pengambilan anggota sampel dari populasi dilakukan secara acak tanpa memperhatikan strata yang ada dalam populasi (Sugiyono, 2008). Jumlah populasi dari Kelompok Tani Sidomakmur I adalah 105 petani. Berdasarkan perhitungan menggunakan rumus Slovin, sampel yang digunakan dalam penelitian ini adalah 51 petani sebagai responden dari populasi sebanyak 105 petani padi.

Analisis efisiensi ekonomi dengan menggunakan fungsi produksi model CobbDouglas yang digunakan untuk mencari koefisien regresi dari setiap faktor produksi. Faktor-faktor produksi yang diduga mempengaruhi jumlah produksi padi di Kelompok Tani Sidomakmur I adalah luas lahan $\left(X_{1}\right)$, jumlah benih $\left(X_{2}\right)$, jumlah pupuk Urea $\left(X_{3}\right)$, jumlah pupuk NPK $\left(X_{4}\right)$, jumlah pestisida $\left(X_{5}\right)$ dan jumlah tenaga kerja $\left(X_{6}\right)$.

Perhitungan analisis efisiensi teknis menggunakan model Cobb- Douglas yang digunakan sebagai berikut (Sumodiningrat, 2001):

$\mathrm{Y}=\mathrm{a} \mathrm{X}_{1}^{\mathrm{b} 1} \mathrm{X}_{2}{ }^{\mathrm{b} 2} \mathrm{X}_{3}{ }^{\mathrm{b} 3} \mathrm{X}_{4}{ }^{\mathrm{b} 4} \mathrm{X}_{5}{ }^{\mathrm{b} 5} \mathrm{X}_{6}{ }^{\mathrm{b} 6} \mathrm{e}^{\mathrm{u}}$

Hubungan fungsional antara faktor-faktor produksi dengan hasil produksi dianalisis menggunakan regresi linier berganda dengan bantuan program SPSS 16, dimana fungsi produksi model Cobb-Douglas tersebut diubah ke dalam bentuk persamaan logaritma natural (In). Model regresi yang digunakan sebagai berikut:

$\operatorname{Ln} Y=\operatorname{Ln} a+b_{1} \operatorname{Ln} X_{1}+b_{2} \operatorname{Ln} X_{2}+b_{3} \operatorname{Ln} X_{3}+$ $b_{4} \operatorname{Ln} X_{4}+b_{5} \operatorname{Ln} X_{5}+b_{6} \operatorname{Ln} X_{6}+u$ 
Agrisaintifika

Jurnal Ilmu-Ilmu Pertanian

Vol. 3, No. 1, 2019

Maharani, et.al. 2017

Keterangan :

$\mathrm{Y} \quad=$ produksi padi $(\mathrm{kg} / \mathrm{musim}$ tanam)

a $=$ konstanta

$\mathrm{X}_{1}=$ luas lahan (ha/musim tanam)

$\mathrm{X}_{2}=$ benih $(\mathrm{kg} /$ musim tanam)

$\mathrm{X}_{3}=$ pupuk Urea $(\mathrm{kg} / \mathrm{musim}$ tanam)

$\mathrm{X}_{4} \quad=$ pupuk NPK $(\mathrm{kg} /$ musim tanam)

$\mathrm{X}_{5}=$ pestisida $(\mathrm{kg} /$ musim tanam)

$\mathrm{X}_{6}=$ tenaga kerja $(\mathrm{HOK} / \mathrm{musim}$ tanam $)$

bi $\quad=$ koefisien regresi

e = bilangan natural $(2,718)$

$\mathrm{u}=$ error/kesalahan

Hubungan faktor-faktor produksi terhadap produksi padi secara serempak dapat diketahui dengan menggunakan uji $\mathrm{F}$ dan hubungan faktor-faktor produksi terhadap produksi padi secara pasrsial dapat diketahui dengan menggunakan uji t.

Analisis efisiensi ekonomi digunakan untuk menganalisis tingkat efisiensi ekonomi penggunaan faktor produksi usahatani padi. Efisiensi ekonomi terjadi pada saat nilai produk marjinal (NPM) dari setiap unit tambahan masukan sama dengan harga dari setiap unit masukan tersebut (Soekartawi, 2003) :

Adanya kaidah pengujiannya adalah sebagai berikut :

a. Penggunaan faktor produksi tidak efisien jika NPM/BKM $<1$

b. Penggunaan faktor produksi sudah efisien jika NPM/BKM = 1

c. Penggunaan faktor produksi belum efisien jika NPM/BKM > 1

\section{HASIL DAN PEMBAHASAN}

\subsection{Profil Kelompok Tani Sidomakmur I}

Kelompok Tani Sidomakmur I merupakan salah satu kelompok tani yang berada di Desa Dengkek Kecamatan Pati. Kelompok tani ini berdiri pada tahun 1987. Kelompok Tani Sidomakmur I berdiri dilatarbelakangi oleh kesamaan dalam menghadapi masalah pertanian terutama masalah hama sehingga warga Desa Dengkek memutuskan untuk bergabung bersama dalam sebuah kelompok tani agar dapat menyelesaikan masalah bersama. Komoditas yang diusahakan pada kelompok tani ini yaitu padi. Varietas yang dibudidayakan antara lain Mekongga, Ciherang dan varietas yang saat ini sedang dibudidayakan yaitu varietas Inpari 32. Jumlah anggota kelompok tani Sidomakmur I sebanyak 105 orang yang semuanya aktif dalam kegiatan kelompok tani. Jumlah petani laki-laki sebanyak 98 orang dan petani perempuan sebanyak 7 orang.

Kelompok tani Sidomakmur I memiliki organisasi pengairan yang diberi nama Darmatirta Sidomakmur. Sistem pengairan pada lahan persawahan milik kelompok tani Sidomakmur I dikelola oleh organisasi pengairan Darmatirta Sidomakmur. Kelompok tani Sidomakmur I menerapkan sistem irigasi teknis atau pompanisasi sejak tahun 1991 sehingga tidak pernah mengalami kekeringan dan dapat melakukan penanaman padi sepanjang tahun yaitu 3 sampai 4 kali musim tanam.

\subsection{Karakteristik Responden}

Responden dari penelitian ini adalah petani padi Kelompok Tani Sidomakmur I. 
Agrisaintifika

Jurnal Ilmu-Ilmu Pertanian

Vol. 3, No. 1, 2019

Maharani, et.al. 2017

karakteristik responden ditentukan berdasarkan usia, lama bertani dan tingkat pendidikan.

Tabel 1. Identitas Responden Petani Padi di Kelompok Tani Sidomakmur I

\begin{tabular}{|c|c|c|c|}
\hline No. & Karakteristik & Jumlah & Persentase \\
\hline & & ----orang---- & ----\%---- \\
\hline \multirow{5}{*}{1.} & Usia (tahun) & & \\
\hline & $31-40$ & 4 & 7,8 \\
\hline & $41-50$ & 19 & 37,3 \\
\hline & $51-60$ & 27 & 52,9 \\
\hline & $>60$ & 1 & 2 \\
\hline \multirow[t]{5}{*}{2.} & Lama Bertani (tahun) & & \\
\hline & $11-20$ & 2 & 3,9 \\
\hline & $21-30$ & 20 & 39,2 \\
\hline & $31-40$ & 26 & 51 \\
\hline & $>40$ & 3 & 5,9 \\
\hline \multirow[t]{5}{*}{3.} & Pendidikan & & \\
\hline & SD & 35 & 68,6 \\
\hline & SMP & 3 & 5,9 \\
\hline & SMA & 12 & 23,5 \\
\hline & D3/S1 & 1 & 2 \\
\hline
\end{tabular}

Sumber : Data Primer Penelitian, 2018.

Tabel 1menunjukkan bahwa jumlah

tinggi pengalaman yang akan mendukung petani yang paling banyak yaitu berada di pekerjaan sehingga dapat meningkatkan kelompok umur 51-60 tahun. Mayoritas usia petani padi di kelompok tani Sidomakmur I berada pada usia produktif. Tingkatan usia seseorang mempengaruhi produktivitasnya dalam bekerja. Hal ini sesuai dengan pendapat Kumbadewi et al. (2016) yang menyatakan bahwa produktivitas karyawan dipengaruhi umur, pengalaman kerja, upah, teknologi dan lingkungan kerja dimana karyawan yang bekerja di usia produktif akan mampu bekerja lebih baik.

Lama bertani petani padi yang paling tinggi yaitu selama 31-40 tahun. Pengalaman kerja salah satunya dipengaruhi oleh lama bekerja. Semakin banyak masa kerja, semakin produktivitas kerja. Hal ini sesuai dengan pendapat Adiati dan Mustika (2013) yang menyatakan bahwa pengalaman kerja berpengaruh secara positif dan signifikan terhadap produktivitas tenaga kerja.

Tingkat pendidikan petani padi tergolong masih rendah, kebanyakan petani hanya tamatan SD. Tingkat pendidikan dapat mempengaruhi produktivitas kerja. Semakin tinggi tingkat pendidikan yang dicapai seseorang maka akan semakin tinggi kemampuan kerja yang dimiliki. Hal ini sesuai dengan pendapat Putri dan Kusreni (2017) yang menyatakan bahwa pendidikan mempunyai peranan penting dalam 
Maharani, et.al. 2017

Agrisaintifika

Jurnal Ilmu-Ilmu Pertanian

Vol. 3, No. 1, 2019

meningkatkan produktivitas tenaga kerja, karena peningkatan produktivitas tenaga kerja yang bertumpu pada pendidikan pada dasarnya

\subsection{Hubungan Faktor-Faktor Produksi Terhadap Produksi Usahatani Padi}

Hubungan antara produksi $(\mathrm{Y})$ dengan faktor produksi (Xi) digunakan model Cobb Douglas. Dari hasil analisis regresi linear berganda diperoleh model sebagai berikut:

$\operatorname{Ln} Y=\ln 7,598+0,810 \operatorname{Ln} X_{1}-0,096 \operatorname{Ln} X_{2}-$ $0,123 \operatorname{Ln} X_{3}+0,201 \operatorname{Ln} X_{4}+0,077 \operatorname{Ln}$ $X_{5}+0,209 \operatorname{Ln} X_{6}$

Hasil regresi yang dilakukan diperoleh nilai koefisien determinasi $\left(R^{2}\right)$ adalah 0,989

Tabel 2. Hasil Analisis Uji F Pengaruh Faktor-Faktor Produksi Terhadap Produksi Padi Secara Serempak

\begin{tabular}{|c|c|c|c|c|c|c|}
\hline Model & Jumlah Kuadrat & Df & $\begin{array}{l}\text { Kuadrat } \\
\text { Tengah }\end{array}$ & F. hit & Sig. & R Square \\
\hline Regresi & 4,990 & 6 & 0,832 & 660,040 & 0,000 & 0,989 \\
\hline Residual & 0,055 & 44 & 0,001 & & & \\
\hline Total & 5,046 & 50 & & & & \\
\hline
\end{tabular}

Sumber : Analisis Data Primer, 2018.

Berdasarkan Tabel 2 diperoleh bahwa nilai signifikansi sebesar 0,000 nilai ini lebih kecil dari $0,05(\alpha=5 \%)$, sehingga dapat disimpulkan penggunaan faktor produksi luas lahan, benih, pupuk urea, pupuk NPK, pestisida dan tenaga kerja secara serempak berpengaruh nyata terhadap produksi padi.

Untuk mengetahui pengaruh masingmasing faktor produksi terhadap produksi padi dilakukan uji $\mathrm{t}$ dengan tingkat kepercayaan $95 \%$.

Tabel 3. Hasil Analisis Uji t Pengaruh Faktor-Faktor Produksi Terhadap Produksi Padi Secara Parsial

\begin{tabular}{clccc}
\hline \hline No. & \multicolumn{1}{c}{ Variabel } & Koefisien & t. Hitung & Sig. \\
\hline 1 & Konstanta & 7,598 & 8,497 & 0,000 \\
2 & Luas Lahan & 0,810 & 16,215 & $0,000^{\star *}$ \\
3 & Benih & $-0,096$ & $-2,067$ & $0,045^{\star *}$ \\
4 & Pupuk Urea & $-0,123$ & $-1,140$ & $0,260^{\text {ns }}$ \\
5 & Pupuk NPK & 0,201 & 3,815 & $0,000^{* *}$ \\
6 & Pestisida & 0,077 & 3,374 & $0,002^{\star *}$ \\
7 & Tenaga Kerja & 0,209 & 1,177 & $0,246^{\text {ns }}$ \\
\hline
\end{tabular}

Sumber : Analisis Data Primer, 2018.

Keterangan : ** : Signifikan ns : Tidak Signifikan

Berdasarkan Tabel 3 diketahui bahwa pestisida memiliki nilai signifikansi lebih kecil variabel luas lahan, benih, pupuk NPK dan dari 0,05 $(\alpha=5 \%)$, sehingga dapat disimpulkan 
Agrisaintifika

Jurnal Ilmu-Ilmu Pertanian

Vol. 3, No. 1, 2019

Maharani, et.al. 2017

bahwa luas lahan, benih, pupuk NPK dan pestisida secara parsial berpengaruh nyata terhadap produksi padi. Variabel pupuk urea dan tenaga kerja memiliki nilai signifikansi lebih besar dari 0,05, sehingga dapat disimpulkan bahwa pupuk urea dan tenaga kerja secara parsial tidak berpengaruh terhadap produksi padi.

Penggunaan faktor produksi luas lahan berpengaruh nyata terhadap produksi padi $(0,000<0,05)$. Variabel luas lahan memiliki nilai koefisien regresi yaitu 0,810 yang berarti bahwa untuk setiap penambahan luas lahan sebesar $1 \%$ dari rata-rata penggunaan lahan 0,81 ha maka akan cenderung meningkatkan produksi padi sebesar $0,81 \%$ dari rata-rata produksi padi $572,5 \mathrm{~kg}$ dengan asumsi variabel lain tetap atau konstan. Lahan merupakan salah satu faktor produksi pertanian yang paling pokok dalam usahatani karena lahan merupakan media petani untuk menanam, tanpa lahan maka petani tidak dapat menjalankan usahataninya. Hal ini sesuai dengan pendapat Mahananto et al. (2009) yang menyatakan bahwa lahan merupakan faktor produksi yang paling utama dalam usahatani, semakin luas lahan yang diusahakan maka semakin tinggi produksi dan pendapatan yang diterima petani.

Penggunaan faktor produksi benih berpengaruh terhadap produksi padi $(0,045<$ $0,05)$. Variabel benih memiliki nilai koefisien regresi $-0,096$. Nilai regresi negatif karena penggunaan benih terlalu banyak sehingga pertumbuhan kurang optimal dan produksi juga akan menurun. Setiap penambahan benih sebesar $1 \%$ dari rata-rata penggunaan bibit 23,84 kg maka akan cenderung menurunkan produksi padi sebesar $0,096 \%$ dari rata-rata produksi padi $5725,5 \mathrm{~kg}$ dengan asumsi variabel lain tetap atau konstan. Benih yang digunakan petani saat ini adalah varietas INPARI 32.Benih merupakan salah satu faktor produksi sebagai penentu tinggi rendahnya hasil produksi.Penggunaan benih yang terlalu banyak dapat menurunkan hasil produksi karena terjadi persaingan dalam penyerapan unsur hara antar tanaman. Hal ini sesuai pendapat Suzana et al. (2011) yang menyatakan bahwa penggunaan benih yang baik dan sesuai dengan aturan akan menghasilkan tanaman budidaya yang baik secara kualitas maupun kuantitas. Penggunaan benih yang terlalu banyak menyebabkan populasi per lubang tanaman tinggi, sehingga terjadi persaingan penyerapan unsur hara, oksigen dan sinar matahari mengakibatkan penurunan produksi.

Penggunaan faktor produksi pupuk urea tidak berpengaruh terhadap produksi padi $(0,260>0,05)$. Variabel pupuk urea memiliki nilai koefisien regresi yaitu -0,123.Nilai koefisien regresi karena penggunaan pupuk urea yang berlebih dan tidak sesuai dengan dosis anjuran. Setiap penambahan pupuk urea sebesar $1 \%$ dari rata-rata penggunaan pupuk urea 134,04 kg maka akan cenderung menurunkan produksi padi sebesar $0,123 \%$ dari rata-rata produksi padi $5725,5 \mathrm{~kg}$ dengan asumsi variabel lain tetap atau konstan Pemberian pupuk urea dilakukan untuk membantu proses pertumbuhan tanaman padi. 
Agrisaintifika

Jurnal Ilmu-Ilmu Pertanian

Vol. 3, No. 1, 2019

Maharani, et.al. 2017

Pupuk urea mengandung unsur nitrogen yang berfungsi membantu pertumbuhan daun, akar dan batang pada tanaman padi.Hal ini sesuai pendapat Jamilah dan Safridar(2012) yang menyatakan bahwa nitrogen bermanfaat bagi pertumbuhan dan perkembangan tanaman. Nitrogen membantu pembentukan bagian vegetasi tanaman seperti daun, akar dan batang serta mempercepat proses sintesis klorofil pada fase vegetatif.

Penggunaan faktor produksi pupuk NPK berpengaruh nyata terhadap produksi padi $(0,000<0,05)$. Variabel pupuk NPK memiliki nilai koefisien regresi yaitu 0,201 yang berarti bahwa untuk setiap penambahan pupuk NPK sebesar $1 \%$ dari rata-rata penggunaan pupuk NPK 243,29 kg maka akan cenderung meningkatkan produksi padi sebesar 0,201\% dari rata-rata produksi padi $5725,5 \mathrm{~kg}$ dengan asumsi variabel lain tetap atau konstan. Pemberian pupuk NPK pada tanaman padi bertujuan memenuhi unsur hara makro yang dibutuhkan tanaman padi untuk pertumbuhan.Pemberian pupuk NPK dapat meningkatkan produksi padi karena pupuk NPK merupakan pupuk majemuk yang mengandung unsur hara $\mathrm{N}, \mathrm{P}$ dan $\mathrm{K}$ sekaligus. Hal ini sesuai dengan pendapat Putra (2012) yang menyatakan bahwa pemberian pupuk NPK menyediakan unsur hara makro primer lengkap dibanding dengan pupuk tunggal, sehingga mampu meningkatkan hasil gabah hingga 58\% lebih tinggi daripada aplikasi pupuk tunggal pada tanaman padi.

Penggunaan faktor produksi pestisida berpengaruh terhadap produksi padi $(0,002<$
0,05). Variabel pestisida memiliki nilai koefisien regresi yaitu 0,077 yang berarti bahwa untuk setiap pestisida sebesar $1 \%$ dari rata-rata penggunaan pestisida 2,41 liter maka cenderungmeningkatkan / mempertahankan produksi padi sebesar $0,077 \%$ dari rata-rata produksi padi $5725,5 \mathrm{~kg}$ dengan asumsi variabel lain tetap atau konstan. Penyemprotan pestisida pada tanaman padi dilakukan petani agar tanaman terhindar dari serangan hama dan penyakit. Penurunan produksi salah satunya disebabkan oleh serangan hama dan penyakit. Hal ini sesuai pendapat Wahyuni et al. (2013) yang menyatakan bahwa serangan hama dan penyakit selama pertanaman merupakan salah satu faktor yang berperan besar dalam penurunan produksi padi.

Penggunaan faktor produksi tenaga kerja tidak berpengaruh terhadap produksi padi $(0,246>0,05)$. Variabel tenaga kerja memiliki nilai koefisien regresi yaitu 0,209 yang berarti bahwa untuk setiap penambahan tenaga kerja sebesar $1 \%$ maka akan cenderung meningkatkan produksi padi sebesar 0,209\% dari rata-rata produksi padi $5725,5 \mathrm{~kg}$ dengan asumsi variabel lain tetap atau konstan. Tenaga kerja yang digunakan yaitu tenaga kerja untuk pembajakan, penanaman padi, pemupukan, penyemprotan dan panen.Tenaga kerja berperan penting dalam usahatani padi karena tanpa tenaga kerja usahatani tidak dapat berjalan dengan baik.Hal ini sesuai dengan pendapat Naqias (2012) yang menyatakan bahwa tenaga kerja merupakan salah satu unsur penentu terutama bagi usahatani yang sangat tergantung musim.Kelangkaan tenaga 
Agrisaintifika

Jurnal Ilmu-Ilmu Pertanian

Vol. 3, No. 1, 2019

Maharani, et.al. 2017

kerja berakibat pada mundurnya penanaman tanaman, produktivitas dan kualitas produk. sehingga berpengaruh pada pertumbuhan

\subsection{Efisiensi Ekonomi Faktor-Faktor Produksi}

Tabel 4. Hasil Analisis Efisiensi Ekonomi

\begin{tabular}{lrcrrrr}
\hline \hline \multicolumn{1}{c}{ Variabel } & \multicolumn{1}{c}{ Xi } & \multicolumn{1}{c}{ Bi } & \multicolumn{1}{c}{ MPP } & NPMxi & BKMxi & \multicolumn{1}{c}{ NPM } \\
\hline Luas Lahan & 0,807 & 0,810 & $5.756,465$ & $27.214 .738,126$ & 7.700 .000 & 3,534 \\
Benih & 23,84 & $-0,096$ & $-23,025$ & $-109.279,091$ & 12.400 & $-8,813$ \\
Pupuk Urea & 134,04 & $-0,123$ & $-5,164$ & $-24.729,204$ & 1.800 & $-13,738$ \\
Pupuk NPK & 243,29 & 0,201 & 4,716 & $22.357,317$ & 2.300 & 9,721 \\
Pestisida & 2,41 & 0,077 & 197,072 & $920.404,268$ & $96.960,78$ & 9,512 \\
Tenaga Kerja & 102,45 & 0,209 & 11,680 & $55.419,925$ & 90.000 & 0,616 \\
\hline
\end{tabular}

Sumber : Analisis Data Primer, 2018.

Berdasarkan Tabel 4 dapat diketahui bahwa nilai efisiensi ekonomi penggunaan faktor produksi luas lahan sebesar 3,534 yang artinya nilai perbandingan antara NPM dan BKM lebih besar dari 1 sehingga penggunaan faktor produksi luas lahan tergolong belum efisien, untuk menjadi efisien faktor produksi luas lahan perlu ditambah. Rata-rata penggunaan lahan di kelompok tani Sidomakmur I sebesar 0,81 ha. Luas lahan merupakan salah satu faktor produksi yang berpengaruh terhadap hasil produksi padi, semakin luas lahan yang digunakan untuk usahatani maka hasil produksi yang dihasilkan juga akan semakin meningkat. Hal ini sesuai dengan pendapat Mahananto et al. (2009) yang menyatakan bahwa lahan merupakan faktor produksi yang paling utama dalam usahatani, semakin luas lahan yang diusahakan maka semakin tinggi produksi dan pendapatan yang diterima petani.

Nilai efisiensi penggunaan faktor produksi benih sebesar $-8,813$ yang artinya nilai perbandingan antara NPM dan BKM lebih kecil dari 1 sehingga penggunaan faktor produksi benih tergolong tidak efisien, untuk menjadi efisien faktor produksi benih perlu dikurangi. Rata-rata penggunaan benih pada kelompok tani Sidomakmur I sebanyak $23,8 \mathrm{~kg}$ per ratarata luas lahan 0,81 ha atau setara $29,38 \mathrm{~kg} / \mathrm{ha}$. Jumlah tersebut melebihi anjuran penggunaan benih dalam satu hektar.Kebutuhan benih dalam satu hektar berkisar 20-25 kg (Purwono dan Purnamawati, 2007).Penggunaan benih yang terlalu banyak dapat menurunkan hasil produksi karena terjadi persaingan penyerapan unsur hara antar tanaman. Hal ini sesuai dengan pendapat Suzana et al. (2011) yang menyatakan bahwa penggunaan benih yang terlalu banyak menyebabkan populasi per lubang tanaman tinggi, sehingga adanya persaingan dalam penyerapan unsur hara, oksigen dan sinar matahari yang mengakibatkan penurunan produksi.

Nilai efisiensi penggunaan faktor produksi pupuk urea sebesar -13,738 yang artinya nilai perbandingan antara NPM dan BKM lebih kecil dari 1 sehingga penggunaan 
Agrisaintifika

Jurnal Ilmu-Ilmu Pertanian

Vol. 3, No. 1, 2019

Maharani, et.al. 2017

faktor produksi pupuk urea tergolong tidak efisien, untuk menjadi efisien faktor produksi pupuk urea perlu dikurangi. Rata-rata penggunaan pupuk urea di kelompok tani Sidomakmur I sebesar $134,04 \mathrm{~kg}$ per usahatani 0,81 ha atau setara $165,48 \mathrm{~kg} / \mathrm{ha}$. Jumlah tersebut sudah melebihi anjuran penggunaan pupuk urea dalam satu hektar.Anjuran penggunaan pupuk urea yaitu $100 \mathrm{~kg} / \mathrm{ha}$ karena usahatani juga menggunakan pupuk NPK (Badan Litbang, 2007).Pemberian pupuk urea harus diperhatikan atau sesuai dengan aturan karena pemberian pupuk urea yang berlebih dapat berdampak buruk pada tanaman padi yaitu menurunkan bobot dan kualitas gabah. Hal ini sesuai dengan pendapat Harahap dan Harahap (2017) yang menyatakan bahwa pemberian unsur nitrogen yang berlebihan pada tanaman padi dapat memberikan efek pada tanaman seperti penurunan daya tahan tanaman terhadap hama dan penyakit, terjadi peningkatan persentase gabah hampa, menurunkan bobot dan kualitas gabah, menghambat pemasakan bahkan dapat menyebabkan tanaman tidak berbunga sama sekali.

Nilai efisiensi penggunaan faktor produksi pupuk NPK sebesar 9,721 yang artinya nilai perbandingan antara NPM dan BKM lebih besar dari 1 sehingga penggunaan faktor produksi pupuk NPK tergolong belum efisien, untuk menjadi efisien faktor produksi pupuk NPK perlu ditambah. Rata-rata penggunaan pupuk NPK di kelompok tani Sidomakmur I yaitu $243,29 \mathrm{~kg}$ per rata-rata luas lahan
0,81 ha atau setara $300,35 \mathrm{~kg} / \mathrm{ha}$. Jumlah tersebut sesuai dengan anjuran penggunaan pupuk NPK dalam satu hektar.Anjuran penggunaan pupuk NPK sebesar 300 $\mathrm{kg} /$ ha.Pemberian pupuk majemuk NPK pada tanaman padi dapat meningkatkan produksi padi karena pupuk NPK memiliki unsur hara makro yang lengkap. Hal ini sesuai pendapat Putra (2012) yang menyatakan bahwa pemberian pupuk NPK menyediakan unsur hara makro primer lengkap dibanding dengan pupuk tunggal, sehingga mampu meningkatkan hasil gabah hingga $58 \%$ lebih tinggi daripada aplikasi pupuk tunggal pada tanaman padi.

Nilai efisiensi penggunaan faktor produksi pestisida sebesar 9,512 yang artinya nilai perbandingan antara NPM dan BKM lebih besar dari 1 sehingga penggunaan faktor produksi pestisida tergolong belum efisien, untuk menjadi efisien factor produksi pestisida perlu ditambah. Rata-rata penggunaan pestisida di kelompok tani Sidomakmur I sebesar 2,41 liter per rata-rata luas lahan 0,81 ha. Penggunaan pestisida pada tanaman padi bertujuan agar tanaman tidak terserang hama dan penyakit karena penurunan produksi padi salah satunya disebabkan oleh serangan hama dan penyakit. Penggunaan pestisida perlu diperhatikan yaitu harus sesuai dengan takaran. Hal ini sesuai dengan pendapat Wahyuni et al. (2013) yang menyatakan bahwa serangan hama dan penyakit selama pertanaman merupakan salah satu faktor yang berperan besar dalam penurunan hasil produksi padi. 
Agrisaintifika

Jurnal Ilmu-Ilmu Pertanian

Vol. 3, No. 1, 2019

Maharani, et.al. 2017

Nilai efisiensi penggunaan faktor produksi tenaga kerja sebesar 0,616 yang artinya nilai perbandingan antara NPM dan BKM lebih kecil dari 1 sehingga penggunaan faktor produksi tenaga kerja tergolong tidak efisien, untuk menjadi efisien faktor produksi tenaga kerja perlu dikurangi. Rata-rata penggunaan tenaga kerja di kelompok tani Sidomakmur I sebesar 102,45 HOK per rata-rata luas lahan 0,81 ha. Penggunaan faktor produksi tenaga kerja yang berlebih mengakibatkan biaya tenaga kerja tidak sebanding dengan produksi yang dihasilkan. Hal ini sesuai pendapat Kuswono et al. (2012) yang menyatakan bahwa penggunaan tenaga kerja lebih dari yang dibutuhkan dapat mengakibatkan peningkatan biaya produksi.

Tingkat efisiensi ekonomi penggunaan faktor-faktor produksi terhadap produksi padi dapat diketahui melalui uji One Sample T Test dengan tingkat kepercayaan 95\%. Hasil uji One Sample $T$ Test dapat dilihat pada Tabel 5.

Tabel 5. Hasil Uji One Sample T Test

\begin{tabular}{clc}
\hline \hline No. & \multicolumn{1}{c}{ Faktor Produksi } & Sig. (2-tailed) \\
\hline 1 & Luas Lahan & 0,000 \\
2 & Benih & 0,000 \\
3 & Pupuk Urea & 0,000 \\
4 & Pupuk NPK & 0,000 \\
5 & Pestisida & 0,000 \\
6 & Tenaga Kerja & 0,000 \\
\hline
\end{tabular}

Sumber : Analisis Data Primer, 2018.

Tabel 5 menunjukkan bahwa hasil uji One Sample $T$ Test dengan test value kriteria efisiensi sebesar 1 yaitu diperoleh nilai signifikansi masing-masing faktor produksi kurang dari 0,05 ( $\alpha=5 \%)$. Nilai tersebut berarti bahwa terdapat perbedaan nyata antara nilai efisiensi ekonomi dengan nilai kriteria efisiensi sebesar 1 atau NPM/BKM tidak sama dengan 1, sehingga dapat disimpulkan bahwa efisiensi ekonomi masing-masing faktor produksi belum atau tidak efisien. Hal ini didukung oleh pendapat Kurniawan (2009) yang menyatakan bahwa nilai tertentu dapat dikatakan berbeda secara nyata dengan rata-rata sebuah sampel apabila nilai signifikansi $\leq 0,05$.

\section{SIMPULAN}

Berdasarkan hasil penelitian pada usahatani padi di kelompok tani Sidomakmur I Kecamatan Pati Kabupaten Pati dapat ditarik kesimpulan sebagai berikut :

1. Penggunaan faktor-faktor produksi luas lahan, benih, pupuk urea, pupuk NPK, pestisida dan tenaga kerja secara serempak berpengaruh terhadap produksi padi. Secara parsial luas lahan, benih, pupuk NPK dan pestisida berpengaruh terhadap produksi padi, sedangkan pupuk urea dan tenaga kerja tidak berpengaruh terhadap produksi padi. 
Maharani, et.al. 2017

Agrisaintifika

Jurnal Ilmu-Ilmu Pertanian

Vol. 3, No. 1, 2019

2. Penggunaan faktor produksi luas lahan, benih, pupuk urea, pupuk NPK dan pestisida pada usahatani padi secara ekonomi belum efisien, sedangkan faktor produksi tenaga kerja secara ekonomi tidak efisien.

\section{DAFTAR PUSTAKA}

Adiati, N. A dan M. D. S. Mutika. 2013. Analisis produktivitas tenaga kerja industry gamelan di Desa Tihingan Kabupaten Klungkung. J. Ekonomi Pembangunan. 2 (5) : 260-268.

Arifin, B. 2005. Pembangunan Pertanian Paradigma Kebijakan dan Strategi Revitalisasi. PT. Grasindo, Jakarta.

Badan Pusat Statistik Jawa Tengah. 2016. Jawa Tengah Dalam Angka 2016. Badan Pusat Statistik Jawa Tengah, Semarang.

Badan Pusat Statistik Kabupaten Pati. 2016. Kecamatan Pati Dalam Angka 2016. Badan Pusat Statistik Kabupaten Pati, Pati.

Badan Penelitian dan Pengembangan Pertanian. 2007. Pengelolaan Tanaman Terpadu (PTT) Padi Sawah, Pedoman Bagi Penyuluh Pertanian. Badan Penelitian dan Pengembangan Pertanian, Jakarta.

Harahap, S. M. dan N. Harahap. 2017. Pemberian beberapa dosis pupuk urea dalam meningkatkan produksi pada tanaman padi di Sumatera Utara. J. Agrica Ekstensia. 11 (1) : 16-21. 
Agrisaintifika

Jurnal Ilmu-Ilmu Pertanian

Vol. 3, No. 1, 2019

Maharani, et.al. 2017

Jamilah dan N. Safridar. 2012. Pengaruh dosis urea, arang aktif dan zeolite terhadap pertumbuhan dan hasil padi sawah (Oryza sativa L.). J. Agrista. 16 (3) : 153-162.

Kumbadewi, L. S., I. W. Suwendra dan G. P. A. J. Susila. 2016. Pengaruh umur, pengalaman kerja, upah, teknologi dan lingkungan kerja terhadap produktivitas karyawan. J. Bisma Universitas Pendidikan Ganesha. 4 (1) : 1-11.

Kuswono, Slamet, dan S. Suratiningsih. 2012. Analisis perbandingan pendapatan usahatani ubi kayu daplang dan jenis markonah di Desa Metaraman Kecamatan Margorejo Kabupaten Pati. J. Agromedia. 30 (2): 70-84.

Mahananto, S. Sutrisno., dan C. F. Ananda. 2009. Faktor-faktor yang mempengaruhi produksi padi studi kasus di Kecamatan Nogosari Kabupaten Boyolali Jawa Tengah. J. Wacana. 12 (1): 59-72.

Naqias, S. 2012. Analisis Efisiensi Penggunaan Faktor-Faktor Produksi dan Pendapatan Usahatani Padi Varietas Ciherang.Institut Pertanian Bogor, Bogor. (Skripsi).

Purwono dan H. Purnamawati. 2007. Budidaya 8 Jenis Tanaman Pangan Unggul. Penebar Swadaya, Jakarta.

Putra, S. 2012. Pengaruh pupuk NPK tunggal, majemuk dan pupuk daun terhadap peningkatan produksi padi gogo varietas Situ Patenggang. J. Agrotrop. 2 (1) : 55-61.

Putri, Y. A. K. D. dan Kusreni, S. 2017. Analisis pengaruh tingkat kesehatan, tingkat pendidikan dan upah terhadap produktivitas tenaga kerja di Indonesia. JIEP. 17 (2) : 67-77.

Singarimbun, M. dan S. Effendi. 2006. Metode Penelitian Survei. LP3S, Jakarta.

Soekartawi. 2003. Teori Ekonomi Produksi dengan Pokok Bahasan Analisis Fungsi Cobb Douglas. Raja Gravindo Persada, Jakarta.

Sugiyono. 2008. Metode Penelitian Kuantitatif, Kualitatif dan R\&D. Alfabeta, Bandung.

Sukirno, S. 2000. Pengantar Teori Mikroekonomi. LPFE UI, Jakarta.

Sumodiningrat, G. 2001. Metode Statistika. Pustaka Sinar Harapan, Jakarta.

Suzana, B. O. L., J. N. K. Dumais dan Sudarti. 2011. Analisis efisiensi penggunaan faktor-faktor produksi pada usahatani padi sawah di Desa Mopuya UtaraKecamatan Dumoga Utara Kabupaten Bolaang Mongondow. J. ASE. 7 (1) : 38-47.

Swastika, D. K. S., Wargiono, Soejitno dan A. Hasanudin. 2007. Analisis kebijakan peningkatan produksi padi melalui efisiensi pemanfaatan lahan sawah di Indonesia. J. Analisis Kebijakan Pertanian. 5 (1) : 36-52.

Wahyuni, S., I. W. Mulsanti dan Satoto. 2013. Produktivitas padi dari kelas benih berbeda. J. IPTEK Tanaman Pangan. $2(2): 62-7$. 